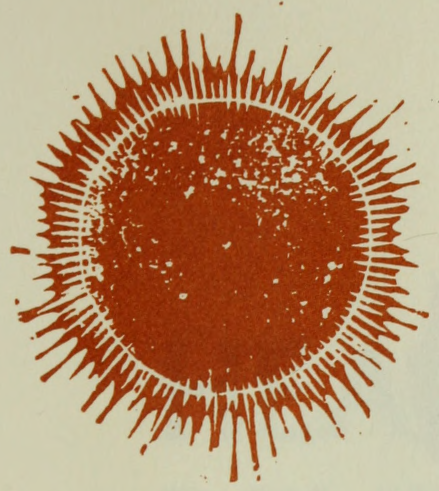

\title{
HEALTH \& THE DEVELOPING WORLD
}




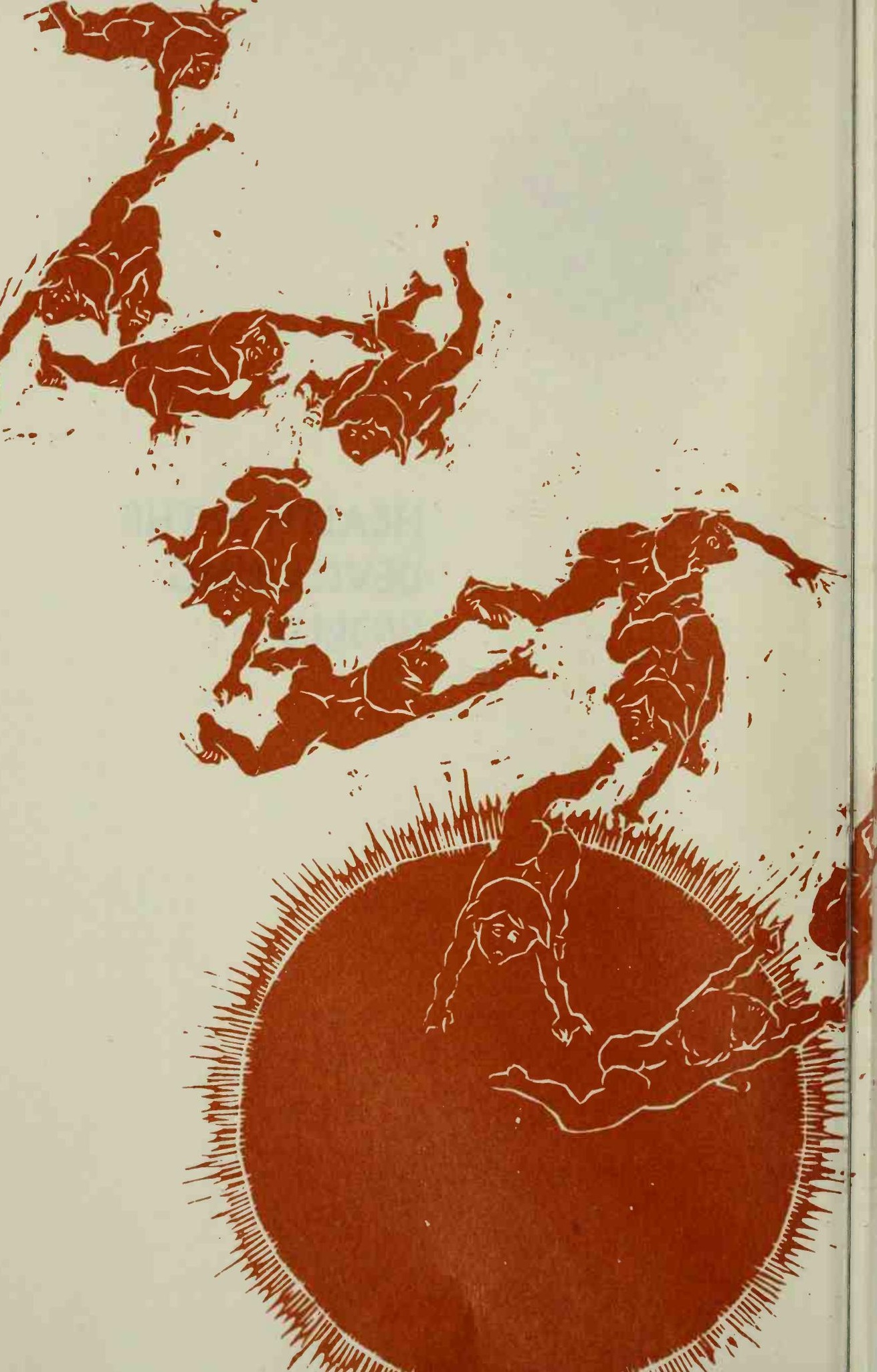




\section{HEALTH \& THE DEVELOPING WORLD}

JOHN BRYANT, M.D.

CORNELL PAPERBACKS

Cornell University Press

Ithaca and London 
Copyright $(\odot 1969$ by The Rockefeller Foundation

All rights reserved. Except for brief quotations in a review, this book, or parts thereof, must not be reproduced in any form without permission in writing from the publisher. For information address Cornell University Press, 124 Roberts Place, Ithaca, New York 14850.

Published in the United Kingdom by Cornell University Press Ltd., 2-4 Brook Street, London W1Y 1AA.

First published 1969 by Cornell University Press

Second printing 1971

Third printing 1972

First printing, Cornell Paperbacks, 1972

International Standard Book Number 0-8014-9129-0

Library of Congress Catalog Card Number 75-87015

Design by Will Bryant

Illustrations by Praphan Srisouta

Composition by Dix Typesetting Co. Inc.

Printed in the United States of America

by Valley Offset, Inc.

Bound by Vail-Ballou Press, Inc. 
To the health workers in developing countries who try to provide health care for all the people. 
Digitized by the Internet Archive in 2012 